\title{
ENDÜLÜS TEFSÎR KÜLTÜRÜ
}

\section{Özet}

Endülüs tefsir kültürünü ele almayı amaçladığımız bu makalede, bölgede oluşan tefsîr anlayışını genel hatlarıyla şu sorulara cevap arayarak ele almak istiyoruz: Endülüs'te tefsîr nasıl ve ne zaman başladı? Endülüs'te tefsîrin öncüleri kimlerdi? Endülüs'te tefsîrin kaynakları nelerdi? Bölge müfessirleri eserlerinde daha çok hangi Tefsîr kitaplarına başvuruyorlardı? Bölgede yaygın olan tefsîr usûlü nasıldı? Çeşitli tefsîr yönelişlerinden hangilerine daha çok ilgi duyuyorlardı? Bölge tefsîrinin özellikleri nelerdi? Endülüs'teki tefsîr anlayışı, diğer İslâm bölgelerinden farklılık arz ediyor muydu? Arz ediyor idiyse bunlar nelerdi? Ve son olarak Endülüs, bütün yönleriyle tefsîrde bir ekol oluşturabildi mi?

Anahtar kelimler: Kur'ân, tefsîr, Endülüs.

\section{Abstract}

\section{The Qur'ān Exegesis Culture in Andalusia}

In this article, that we aim to examine the Qur'an exegesis culture in Andalusia, we want to handle the perception of Qur'an exegesis by searching answers for the following questions in general terms: How and when the Qur'an exegesis started in Andalusia? Who were the pioneers of the exegesis in Andalusia? What were the references of the exegesis in Andalusia? Which tafsirs were the exegesis in the region referring to? What was the methodology of exegesis in the region? Which procedure were commentators interested in among the assorted commentary drifts? What were the characteristics of interpretation in the region? Was there any difference in understanding of the Qur'an exegesis in Andalusia by comparison with other Islamic regions? If it was so, what were they? And finally, could Andalus create a school in tafsir in every respect?

Keywords: Qur'an, exegesis, Andalusia.

Müslümanların Avrupa kıtasında, bugünkü İspanya sınırları içinde kurmuş oldukları Endülüs, medeniyet tarihinde izleri hâlâ görülebilen derin etkiler bırakmış; bu nedenle de geçmişten günümüze tarih, bilim ve kültür araştırmalarının konusu olagelmiştir. Bu çalışmada Endülüs' teki Kur'ân ve tefsîr kültürünü yakından incelemek sûretiyle söz konusu araştırmalara katkıda bulunmak amacını taşımaktayız. Makalemizde "tefsîr kültürü" kavramını çalışmamızın

* $\quad$ Yrd. Doç. Dr., Bayburt Ü. İlahiyat Fakültesi. 
özetinde sorduğumuz soruların cevaplarını oluşturacak nitelikler bağlamında kullanacağız.

İlk defa 98/716 yılında basılmış bir sikke üzerinde rastlanan Endülüs kelimesinin kökeni tam olarak tespit edilememiş, Güney İspanya' da bir süre yaşamış olan Vandallar'ın adından (Vandalus, Vandalicia) türemiş olabileceği belirtilmiştir. ${ }^{1}$

Başlarda müslümanların İspanya' da hâkim oldukları toprakların tamamına Endülüs denilirken Miladî XI. yüzyıldan itibaren bu coğrafya daralmaya başlamış ve sonunda Benî Ahmer Emirliği'nin idaresindeki topraklarla sınırlı kalmıştır. Günümüz İspanya'sında hâlâ kullanılan Andalucia adı, Almeria (elMeriye), Granada (Gırnata), Jaén (Ceyyân), Cordoba (Kurtuba), Sevilla (İşbîliye), Huelva (Velbe), Malaga (Mâleka) ve Cadiz (Kâdis) şehirlerini içine alan bölgeyi kapsamaktadır. ${ }^{2}$

Endülüs'ün fethi ile ilgili rivâyet ve tartışmaları ${ }^{3}$ konumuz dışında olduğu için bunu bir yana bırakıp fethin, genellikle kabul edildiği üzere 92/710 yılında başladığını ve Emevîler'in Kuzey Afrika Vâlisi tâbiûndan Mûsâ b. Nusayr (98/717) ile onun görevlendirdiği Târık b. Ziyâd (101/720) komutasındaki ordular tarafından 94/712 yılında tamamlandığını belirtmekle yetineceğiz. ${ }^{4}$

Fetihten sonra Endülüs'te 96/714'ten 139/756'a kadar 21 vâlinin görev yaptı̆̆g “Vâliler Dönemi”, I. Abdurrahman'ın bağımsızlığını ilan ettiği ve emirlik ve halîfelik olmak üzere iki dönem geçiren "Endülüs Emevîleri” (139-423/756-1031), merkezî otoritenin dağılmasından sonra küçük şehir devletleri tarzında karş1mıza çıkan "Mülûkü’t-Tavâif Dönemi" (423-483/1031-1090), Yusuf b. Taşfîn önderliğinde "Murâbıtlar" (483-542/1090-1147), Ebû Yusuf el-Mansûr yönetiminde "Muvahhidler" (542-627/1147-1229) ve son olarak Muhammed b. Nasr tarafından Gırnata'da kurulan “Benî Ahmer Emirliği”" (636-898/1238-1492) dö-

1 Mehmet Özdemir, "Endülüs", DİA (Türkiye Diyanet Vakfı İslam Ansiklopedisi), İstanbul 1995, c. 10, s. 211. Kelimenin kökeninin Vizigotlar'ın kullandıkları “Landahlouts" kelimesinden türemiş olabileceği ve diğer görüşler ile ilgili ayrıntılı bilgi için bk. Ali Dadan, "Endülüs Adının Kökeni Üzerine", ISTEM, Konya, 2009, sayı: 14, ss. 373-375.

2 Özdemir, agm, c. 10, s. 211.

3 Bu konuda ayrıntılı bilgi için bk. S. Muhammed İmamüddin, Endülüs Siyasi Tarihi, çev.: Yusuf Yazar, Rehber Yay., Ankara 1990, ss. 29-43; İsmail Hakkı Atçeken, “Endülüs'ün Fetih Süreciyle İlgili Farklı Görüşlere Eleştirel Bir Yaklaşım”, Selçuk Üniversitesi İlâhiyât Fakültesi Dergisi, Konya, 2005, sayı: 19, ss. 17-30.

4 Özdemir, agm, c. 10, ss. 211-212. 
nemleri yaşanmıştır. ${ }^{5}$

Endülüs Emevîleri'nin en parlak dönemi, III. Abdurrahman (300-350/912961), oğlu II. Hakem (350-366/961-976) ve ondan sonra gelen İbn Ebî Âmir'in (el-Hâcib el-Mansûr) (367-393/977-1002) yönetimlerindeki bir asra yaklaşan dönem olmuştur. ${ }^{6}$ Philip Hitti'ye göre bu dönemde Kurtuba, Avrupa'nın en ileri kültür düzeyine sahip şehri olarak İstanbul (o zamanki adıyla Konstantinopolis) ve Bağdat ile birlikte dünyanın önde gelen üç büyük kültür merkezinden biridir. 113.000 evi, 21 dış mahallesi, 70 kütüphânesi ve câmileri, sarayları, hamamları, taş döşeli ve aydınlatmalı sokaklar ile Kurtuba, hem gelişmiş bir şehir hem de endüstrisi ve sulu tarıma uygun alt yapısıyla dikkat çeken bir merkezdir. Özellikle ilmi ve âlimleri seven, kendisi de bir âlim olan II. Hakem'in himayesiyle şehirde ücretsiz eğitim yapan 27 okul kurulmuştur. Günümüz üniversiteleri düzeyinde eğitim veren Kurtuba Medresesi de bizzat II. Hakem'in kurduğu 400.000 yazma eser bulunduran kütüphanesi ile henüz M1sır'daki Ezher ve Bağdat'taki Nizâmiye medreselerinin kurulmadığı bir dönemde, dünya çapında bir eğitim merkezi haline gelmiştir.7

\section{Endülüs'te Tefsîr Nasıl ve Ne Zaman Başladı?}

Tarih bize yeni bir coğrafyaya giren bir medeniyetin dinini, dilini ve kültürünü oraya götürdügüunü ve oraya bir bütün olarak yerleştiğini göstermiştir. Endülüs'ü fetheden Müslümanlar da geldikleri coğrafya ile bağlarını koparmamış ve doğu ile karşılıklı gidiş-gelişlerini hep sürdürmüşlerdir. Üstelik bu yolculuklar sadece ticarî maksatla değil aynı zamanda ilmî ve kültürel sebeplerle de yapıla gelmiştir. ${ }^{8}$ İslâmlaşmanın ardından Kur'ân'ın dili olması, toplumun ihtiyaçlarına cevap verebilecek kadar zengin olması, Endülüslüler'in ve yöneticilerinin önem vermesi gibi sebeplerle Arap dilinin Endülüs'te iletişimi sağlayan bir dil niteliği kazanması çok uzun sürmemiştir. ${ }^{9}$ İlerleyen süreçte resmî dilin Arapça olması ve eğitimin bu dille yapılması neticesinde Arapça, IX. yüzyılın ortalarından itibaren Müslüman halkın tamamının, hatta gayri müslimlerin ortak

5 Özdemir, agm, c. 10, ss. 211-216.

6 Philip K. Hitti, Siyâsî Ve Kütürel İslam Tarihi, çev.: Salih Tuğ, Boğaziçi Yay., İstanbul 1980, c. 3, s. 831; Özdemir, agm, c. 10, ss. 213-214

7 Bu bilgiler ve daha fazlası için bk. Philip K. Hitti, age, c. 3, ss. 831-841.

8 Mustafa İbrâhîm el-Meşîn̂, Medresetü't-Tefsîr fi'l-Endelüs, Müessesetü'r-Risâle, Beyrut 1986, ss. 29-30.

9 Meşînî, age, ss. 34-37. 
konuşma ve yazı dili haline gelmiştir. ${ }^{10}$

İslâm ilimleri Endülüs'e, bir yandan fetih için gelen Müneyzir el-İfrîkî gibi bazı sahabe ve Mûsâ b. Nusayr (97/715), Haneş es-San'anî (100/718) ve Ali b. Rabâh el-Lahmî (114/732) gibi tâbiûn aracillğıyla; öte yandan bu ilk öncülerin ardından Endülüslü bazı âlimlerin, ilim öğrenmek ve oluşan yeni toplumun ihtiyaçlarına açılımlar sağlayacak birikimler elde etmek maksadıyla doğuya, bu ilimlerin merkezine doğru seyahatlerde bulunmaları sonucunda girmiştir. ${ }^{11} \mathrm{Bu}$ çerçevede Endülüs'te en çok önem verilen ilimlerin tefsîr, kırâat ve fıkıh olduğu belirtilmiştir. ${ }^{12}$

Kırâat ilmi, gerek Hz. Peygamber'in (sas) hayatında gerekse vefatından sonra Kur'ân'ın okunması ve yazıya geçirilmesi sürecinde ortaya çıkan kırâat ihtilafları dolayısıyla sahîh ve mütevâtir olanını şâz olanından ayırmak ve böylece Kur'ân'ın lafızlarını tahrîften korumak amacıyla sahabenin Kur'ân'dan ilk öğrendiği ilim kabul edilir. Bundan dolayı kırâat ilminin Endülüs'e girişi de değindiğimiz gibi ilk dönemde, sahabe ve tâbiûn eliyle olmuştur. Endülüs ulemâsı, fetihle birlikte kendilerine doğudan gelen kırâatleri almışlar ve herhangi bir açıklama ve eleştiriye tâbi tutmadan kabul etmişlerdir. ${ }^{13}$

İbnü'l-Cezerî'ye göre Kırâat ilmini Endülüs'e ilk getiren kişi, İmam Nâfi'den (169/785) bizzat okumuş ve yazmış olan Gâzî b. Kays Ebû Muhammed el-Endelûsî (199/814); Endülüs'te bu alanda ilk eser veren kimse de Ebû Ömer Ahmed b. Muhammed b. Abdullah et-Talemnekî (429/1037)'dir. ${ }^{14} \mathrm{Bu}$ coğrafyada Kırâat ilminin yayılması şerefi ise İbrahim el-Meşîn̂̂’ye göre Mücâhid el-Âmirî’ye (436/1044) aittir. ${ }^{15}$ Ona göre Endülüs'te Kırâat ilmi sahasında üç ismin akla gelir. Bunlar sırasıyla Mekkî b. Ebî Tâlib (437/1045), Ebû

10 Özdemir, agm, c. 10, s. 219.

11 Meşînî, age, ss. 39-44.

12 Muhammed Abdülhamîd Îsâ, Târîhu't-Ta'lîm fi'l-Endelüs, Dâru'l-Fikri'l-Arabî, yy., 1982, s. 283.

13 Meşînî, age, ss. 67-68.

14 Muhammed İbnü'l-Cezerî (833/1429), Gâyetü'n-Nihâye fì Tabakâti'l-Kurrâ', Misır, 1932, c. 1, s. 120, c. 2, ss. 2-3; Abdüsselâm Ahmed el-Kenûnî, el-Medresetü'l-Kur'âniyye fi'l-Magrib, Mektebetü'l-Maârif, Rabat, 1981, c. 1, ss. 54-55; M. Kemal Atik, “Endülüs ve Kur'an İlimlerindeki Yeri", Erciyes Ü. İlâhiyât Fakültesi Dergisi, sayı: 2, Kayseri 1985, ss. 277-278. Sa'd Abdullah Sâlih el-Beşerî, el-Hayâtü'l-İlmiyye fì Asri Mülûki't-Tavâif fi'l-Endelüs, Riyad 1993, ss. 266-269.

15 Meşînî, age, s. 68. İbn Haldun'a göre de Mücâhid Âmirî, Kırâat ilmine özen göstermiş ve bölgede Kırâat ilminin öğretilmesinde ve yayılmasında çok önemli çabaları olmuştur. Bk. Abdurrahmân İbn Haldun (808/1405), Mukaddime, Dâru İhyâi't-Türâsi'l-Arabî, Lübnan, ts., s. 437. 
Amr ed-Dânî (444/1052) ve Ebu'l-Kâsım eş-Şâtıbî'dir (590/1193). ${ }^{16}$

Makkarî'nin nakline göre Endülüslülerin nazarında Kırâat ilminin değeri yüksektir, çünkü o fıkıh için yol gösterici, prestiji yüksek bir ilimdir. ${ }^{17}$ Meşînî de Osman Mushafı' nın Endülüs' te yaygın olmasının ve ona büyük değer verilmesinin bunu te'yîd ettiğini belirterek, bu coğrafyanın bütün yerleşim birimlerinde yaygın kırâatın Medîneli İmam Nâfi'in kırâatı olduğunu söyler. ${ }^{18}$

Endülüste yaygın kırâat eserleri Ebû Ubeyd Kasım b. Sellâm'ın (224/838) Kitâbü'l-Kırâât'1, Ebû Bekr b. Mücâhid'in (324/935) İhtilâfü'Kırâât ve Tasrîfü Vücûhihâ'sı, Ebu'l-Hasen b. Galbûn'un (399/1008) el-Mürşid fi'l-Kırââti's-Seb' ve etTezkira fi'l-Kırâât'ı, Mekkî b. Ebî Tâlib'in et-Tebsıra'sı, Ebû Amr ed-Dânî'nin etTeysîr' ${ }^{19}{ }^{19}$ ve İbn Şureyh'ın (476/1083) el-Kâfi'sidir. ${ }^{20}$

Endülüs'te tefsîr ilmine gelince, tefsîrin bölgede Hz. Peygamber döneminde olduğu gibi, Kur'ân'ın teblîği çalışmalarının bir parçası ve şifâhî olarak başladığı yaklaşımının ${ }^{21}$ ötesinde müstakil bir disiplin şeklinde tam olarak ne zaman başladığının belirlenmesi çok mümkün değildir. ${ }^{22} \mathrm{Bu}$ tarih belirleyememe durumunun sebepleri arasında İslâm geleneğinde âlimlerin bir alanda meşhur olsalar da bütün İslâm ilimlerinde yetkin olmaları yani aynı zamanda müfessir, muhaddis, fakîh kabul edilmeleri ve Endülüs şehirlerinde bulunan câmilerdeki ders halkalarında İslâmî ilimlerin hepsinin okutulması sayılabilir. ${ }^{23}$

Kenûnî'ye göre Doğu İslâm Dünyası'ndan Batı İslâm Dünyası'na ilk giren

16 Meşînî, age, ss. 69-76. Kemal Atik de bölgenin en önemli Kırâat âlimleri hakkında bilgi verirken yukarıda sözünü ettiğimiz Talemnekî'den sonra bu üç ismi sayar. Bk. M. Kemal Atik, agm, ss. 278-280. Endülüs'ün meşhur kurrâsı ve kırâat alanında yazılan eserler için bk. Kenûnî, age, c. 1, ss. 65-85; Muhammed Abdülhamîd Îsâ, age, ss. 286-294.

17 Ahmed b. Muhammed el-Makkarî (1041/1632), Nefhu't-Tîb, tahk.: İhsan Abbâs, Dâru Sâdır, Beyrut 1968, c. 1, s. 221.

18 Meşînî, age, s. 69. Benzer bir değerlendirme için bk. Yûsuf b. Ali b. İbrâhîm el-Arînî, elHayâtü'l-ïlmiyye fi'l-Endülüs fì Asri'l-Muvahhidîn, Riyad, 1995, s. 214.

19 Ebû Amr ve et-Teysîr hakkında ayrıntılı bilgi için bk. F. Asiye Şenat Kazancı, "Endülüslü Kıraat Âlimi Dânî ve Tefsîr'i", Türk-İslâm Medeniyeti Akademik Araştırmalar Dergisi, sayı: 10, Konya 2010, ss. 175-186.

20 Arînî, age, ss. 215-216.

21 İbrâhîm Ahmed el-Vâfî, "et-Tefsîr Ve Ulûmu'l-Kur'âni bi'l-Garbi'l-İslâmiyyi mine'l-Karni'sSânî ile'1-Karni's-Sâmini'l-Hicrî", es-Sicillü'l-Ilmiyyü li Nedveti'l-Endelüs haz.: Abdullah b. Ali ez-Zeydân, vd., Riyad 1996, ss. 11-12.

22 Benzer değerlendirmeler için bk. Meşînî, age, s. 79; Yunus Ekin, "Endülüs Tefsir Geleneği", Sakarya Üniversitesi İlâhiyât Fakültesi Dergisi, sayı: 3, Sakarya 2001, s. 249.

23 Meşînî, age, ss. 79-80. 
tefsîrler İbn Abbâs (68/687), Hasan Basrî (110/728), Abdullah b. Nâfi' (206/822), Zeyd b. Eslem (182/798), Abdürrezzak es-Sam'ânî (211/826), Kasım b. Sellâm (224/838) ve Taberî́nin (310/922) tefsîrleridir. ${ }^{24}$ Nitekim bölgenin öncü müfessirlerinden Mekkî b. Ebî Tâlib (437/1045) tefsîrinin mukaddimesinde; tefsîr kaynakları olarak hocası Ebû Bekr el-Edfevî'den (388/998) başka, sırasıyla Taberî, Nehhâs (338/949), Zeccâc (311/923), İbn Abbâs (68/687), (Kâsım) b. Sellâm ve Ferrâ (207/822) gibi müfessirlerin isimlerini zikreder. ${ }^{25}$

Ahmed el-Vâfî, Endülüs'te Taberî kadar meşhur olmasa da h. II. asrın sonlarında Yahyâ b. Sellâm'ın (200/815) tefsîrinin okutulmakta olduğunu söyler. ${ }^{26}$ Yine Vâfî’nin de belirttiği gibi Yahyâ b. Sellâm'ın tefsîrinin rivâyet ile dirâyeti birleştirmesi, başka bir deyişle Taberî'nin tefsîri ile aynı özelliği taşıması, birinin yerine diğerinin geçmesini kolaylaştırmış olsa gerektir. Ayrıca yüzyıllara göre verdiğimiz eser listelerinde de görüleceği gibi bu iki tefsîrin çokça muhtasarının yapılmış olması, bölgede ne kadar yaygın olduklarının bir göstergesi sayılabilir.

Bu takdirde tefsîrin diğer İslâm ilimleri ile birlikte Endülüs'ün İslamlaşması sürecinde bölgeye girdiği, ayrı bir disiplin olarak tefsîr faaliyetlerinin başlangıcının yaklaşık olarak h. III. asra tarihlenebileceği söylenebilir. ${ }^{27}$

\section{Endülüs'te Tefsîrin Öncüleri}

Belirttiğimiz gibi h. III. asır, Endülüs'te müfessirlerin görünür olmaya başladığı dönemdir. Vâfî’ye göre bu dönemde Endülüs'te tefsîrle ilgilenen ve eser veren âlimler şunlardır:

\section{1. H. III. Yüzyıl Tefsîr Bilginleri ve Eserleri}

\begin{tabular}{|l|l|}
\hline Müellif & Eserleri \\
\hline Abdurrahmân b. Mûsâ el-Hüvvârî (228/842) & Kitâbün fì Tefsîri'l-Kur'ân \\
\hline Abdülmelik b. Habîb (239/853) & Tefsîru'l-Kur'ân \\
\hline İbrâhîm b. Hâlid el-Kurtubî (249/863) & Tefsîru'l-Kur'ân \\
\hline
\end{tabular}

24 Kenûnî, age, c. 1, ss. 127-133.

25 Mekkî b. Ebî Tâlib Ebû Muhammed (437/1045), el-Hidâye ilâ Bülûgi'n-Nihâye, tahk.: eş-Şâhid el-Buşeyhî, vd., Mecmûatü Buhûsi'l-Kitâbi ve's-Sünne, Câmiatü'ş-Şârika, 2008, c. 1, ss. 74-75.

26 Vâfî, age, s. 15.

27 Meşînî, age, ss. 81-82. 


\begin{tabular}{|l|l|}
\hline Muhammed b. Sehnûn (256/869) & Ahkâmü'l-Kur'ân \\
\hline Muhammed b. Abdûs (261/874) & Kitâbü't-Tefsîr fì Ebvâbin mine'l-Fıkh \\
\hline Bakî b. Mahled (276/889) ${ }^{28}$ & Kitâbün fì Tefsî̀r'l-Kur'ân \\
\hline
\end{tabular}

Mevcut bilgilere göre Bakî b. Mahled (276/889), Endülüs'te tefsîr ile ilgilenen ilk âlimlerdendir. ${ }^{29}$ İbn Hazm'a (456/1064) göre onun Tefsîru'l-Kur'ân adlı eseri, Taberî'nin tefsîri dâhil tefsîrlerin en güzelidir. ${ }^{30}$ Bu tefsîrin günümüze

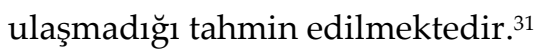

\section{2. H. IV. Yüzyıl Tefsîr Bilginleri ve Eserleri}

H. IV. asır, Endülüs'te tefsîr alanında ilmî çabaların göründüğü ve bu çabalardan faydalı sonuçların elde edildiği asırdır. Bu dönemde bölge müfessirleri tefsîre katkıda bulunmaya, ayrıca gerek o ana kadar yazılan tefsîrlere muhtasar gerekse de Ahkâmü'l-Kur'ân ve Ulûmu'l-Kur'ân sahalarında yeni eserler yazmaya başlamışlardır. Bu dönemde doğu İslâm dünyasına yolculuk yaparak oradaki tefsîr birikimini batı İslâm dünyasına aktarmaya çalışan çok sayıda âlim yetişmiştir. Bu dönemde tefsîr (üzerine) yazan müellifler şunlardır:

\begin{tabular}{|l|l|}
\hline Müellif & Eserleri \\
\hline Ebu'l-Esved el-Kattân (309/921) & Ahkâmü'l-Kur'ân \\
\hline Ahmed b. Ziyâd el-Fârisî el-Kayravânî (319/931) & Ahkâmü̈l-Kur'ân \\
\hline $\begin{array}{l}\text { Abdullah b. Muhammed b. Huneyn (318-319 ?/930- } \\
931 \text { ?) }\end{array}$ & Ihtisâru Tefsîri Bakî b. Mahled \\
\hline Abdullah b. Mutarrif İbn Âmine el-Kurtubî (340/951) & Kitâbün fî Tefsîri'l-Kur'ân \\
\hline Kasım b. Esbağ el-Beyyânî el-Kurtubî (340/951) & $\begin{array}{l}\text { Ahkâmü'l-Kur'ân alâ Grrâri Kitâbi'l-Kâdı } \\
\text { el-Bağdâdî }\end{array}$ \\
\hline Münzir b. Saîd el-Bulûtî (355/965) & Ahkâmü'l-Kur'ân \\
\hline Ebû Ali el-Kâlî (356/966) & Tefsîru's-Seb'ı't-Tivâl \\
\hline Nu'man b. Hayevân et-Temîmî (363/973) & Esâsü't-Te'vîll \\
\hline $\begin{array}{l}\text { Muhammed b. Abdullah İbn Ebî Zemeneyn } \\
\text { (398/1007) }{ }^{32} \text {. }\end{array}$ & Muhtasaru Tefsîri Yahyâ b. Sellâm \\
\hline
\end{tabular}

28 Vâfî, age, ss. 16-17, 60. Benzer yaklaşım için bk. Kenûnî, age, c. 1, ss. 134-154.

29 Meşîn̂, age, s. 81.; Kemal Atik, agm, ss. 281-282. Arînî, age, s. 222; Sa'd Abdullah Sâlih elBeşerî, el-Hayâtü'l-İlmiyye fì Asri'l-Hılâfe fi'l-Endelüs, Mekke, 1997, s. 195.

30 Makkarî, age, c. 2, s. 519.

31 M. Yaşar Kandemir, "Bakî b. Mahled", DİA, (Türkiye Diyanet Vakfı İslam Ansiklopedisi), İstanbul, 1991, c. 4, s. 542.

32 Vâfî, age, ss. 18-23, 60. H. IV. asır müfessirleri ile ilgili olarak ayrıca bk. Kenûnî, age, c. 1, ss. 


\section{3. H. V. Yüzyıl Tefsîr Bilginleri ve Eserleri}

H. V. asır, Endülüs'te tefsîre ve Kur'ân ilimlerine çok önem verildiği ve Mekkî b. Ebî Tâlib (437/1045), Mehdevî (430/1038), Zehrâvî (431/1039), İbnü'l-Cevzî (483/1090), el-Bâcî (474/1081) gibi Endülüs tefsîrinin omurgasını oluşturan müfessirlerin yaşadığı bir dönem olmuştur. Bu dönemde tefsîr alanında eser veren müellifler şunlardır:

\begin{tabular}{|c|c|}
\hline Müellif & Eserleri \\
\hline Ahmed b. Ali er-Rub'î el-Bâganî (401/1010) & Ahkâmüll-Kur'ân \\
\hline Ebu'1-Mutarrif Abdurrahmân b. Hârûn (413/1022) & Muhtasaru Tefsîri İbn Sellâm \\
\hline İbn Berid Ahmed b. Muhammed (418/1027) & et-Tahsîl fì Tefsîri'l-Kur'ân \\
\hline Ebû Yahyâ İbn Samâdih (419/1028) & Muhtasaru Tefsîri't-Taberî \\
\hline Ahmed b. Muhammed et-Talemnekî (429/1037) & Kitâbün fî Tefsîri'l-Kur'ân \\
\hline Ebu'1-Velîd İbnü's-Saffâr (429/1037) & Kitâbü't-Tefsîr \\
\hline Ali b. Süleyman ez-Zehrâvî (431/1039) & Kitâbün Kebîrun fì Tefsîri'l-Kur'ân \\
\hline $\begin{array}{l}\text { el-Mühelleb İbn Ebî Safra et-Temîmî (435-436 ?/1043- } \\
1044 \text { ?) }\end{array}$ & Kitâbü't-Tefsîr min Sahîhi'l-Buhârî \\
\hline Mekkî b. Ebî Tâlib (437/1045) & $\begin{array}{l}\text { el-Hidâye fi't-Tefsîr } \\
\text { el-Me'sûr an Mâlik fi'l-Ahkâmi ve't-Tefsîr } \\
\text { Ihtisâru Ahkâmi'l-Kur'ân } \\
\text { Tefsîru Müşkili'l-Maânî ve't-Tefsîr }\end{array}$ \\
\hline Ahmed b. Ammâr el-Mehdevî (440/1048) & $\begin{array}{l}\text { et-Tafsîlü̈'l-Câmi' li Ulûmi't-Tenzîl } \\
\text { et-Tahsîl li Fevâiidi't-Tafsîl }\end{array}$ \\
\hline Ebû Amr ed-Dânî (444/1052) & Tefsîr \\
\hline Ebu'l-Velîd el-Bâcî (474/1081) & Tefsîru'l-Kur'ân (Tamamlayamadı) \\
\hline $\begin{array}{l}\text { Ali b. Faddâl b. Ali et-Temîmî el-Kayravânî } \\
(479 / 1086)\end{array}$ & $\begin{array}{l}\text { el-Burhânü'l-Amîdî fì Tefsîri'l-Kur'ân } \\
\text { Şerhu'l-Besmele } \\
\text { en-Nüket fi'l-Kur'ân } \\
\text { el-İksîr fì Ilmi't-Tefsîr }\end{array}$ \\
\hline Ebû Bekr İbnü'l-Cevzî es-Sebtî (483/1090) & Tefsîrini tamamlayamamıştır \\
\hline $\begin{array}{l}\text { İbnü'l-Murâbit Ebu'l-Velîd Muhammed b. Halef } \\
\text { (485/1092) }\end{array}$ & Kitâbü't-Tefsîr min Sahîhi'l-Buhârî \\
\hline Ebû Abdullah b. el-Licâliş $(490 / 1096)^{33}$ & Muhtasaru Tefsîri't-Taberî \\
\hline
\end{tabular}

163-174.

33 Vâfî, age, ss. 23, 27-30, 61-62. H. V. asır müfessirleri ile ilgili olarak ayrıca bk. Kenûnî, age, c. 1, ss. $175-189$. 
Endülüs'te Bakî b. Mahled (276/889), Mekkî b. Ebî Tâlib (437/1045), Ahkâmu'l-Kur'ân'ın müellifi Ebû Bekr İbnü'l-Arabî (543/1148), el-Muharraru'lVecîz sahibi İbn Atıyye (541/1147), el-Câmi' li Ahkâmi'l-Kur'ân yazarı Ebû Bekr b. Ferh el-Kurtubî (671/1272), et-Teshîl li Ulûmi't-Tenzîl adlı eseriyle bilinen İbn Cüzey el-Kelbî (741/1340) ve el-Bahru'l-Muhît'in müellifi Ebû Hayyân elEndelüsî (745/1344), bölgede tefsîr ilminin belli başlı meşhûr âlimleri olarak dikkati çekmektedir. ${ }^{34}$

Sonuç olarak Endülüs'te tefsîr, h. III. asırda ayrı bir ilim olarak ortaya çımış, V. asırda parlak bir dönem geçirmiş ve İbn Atıyye ile VI. asırda Meşîn̂̀'nin ifadesiyle zirveye ulaşmıştır. ${ }^{35}$ Tefsîr ile ilgilenenler tarafından yukarıda adı geçen müfessirlerin meşhur olanlarından İbn Atıyye ve Ebû Hayyân'ın tefsîrlerinin dil, İbnü'l-Arabî ve Kurtubî'nin tefsîlerinin ise ahkâm yönlerinin baskın olduğu bilinmektedir.

\section{Endülüs'te Tefsîrin Kaynakları}

Klasik tefsîr anlayışına göre Kur'ân'ın ilk ve en güzel tefsîri yine kendisidir. ${ }^{36}$ Çünkü Kur'ân'ın bir kısmı diğer kısmını açıklar. Bir yerde mücmel olan başka bir yerde detaylandırılır, bir yerde mübhem olan başka bir yerde tefsîr edilir; yine bazı yerlerde Kur'ân umûmun tahsîsini ve mutlakın takyîdini kendisi yapar. Daha önce belirttiğimiz gibi tefsîr kaynaklarının ikincisi ise doğal olarak sünnettir. Çünkü Hz. Peygamber (sas) Allah'ın elçisidir, vahyin ilk muhatabı, ilk tebliğcisi ve ilk uygulayıcısıdır. Bu açıdan sünnetin Kur'ân'ı tefsîri de Kur'ân'ın te'kîdi, mücmel ve müşkilin açılanması ve umûmun tahsîsi ile mutlakın takyîdi şeklinde olmaktadır. ${ }^{37} \mathrm{Bu}$ iki başat kaynaktan yani Kur'ân ve sünnetten sonra tefsîr kaynağı olarak sahabe kavlini görmekteyiz. Takdîr edilir ki

34 Meşînî, age, ss. 83-108.

35 Meşinî, age, ss. 80-81. Benzer bir değerlendirme için bk. Arînî, age, s. 224. Ayrıca h. 6. asrın tefsîr açısından önemli bir dönüm noktası olduğu ve bu asrın en önemli müfessirlerinden birinin İbn Atıyye olduğu ile ilgili olarak bk. Vâfî, age, ss. 32-33. Ayrıca rivâyet tefsîrinin zirvelerinden olduğu ile ilgili bk. Fehd İbn Abdurrahmân İbn Süleymân er-Rûmî, "Menhecü'lMedreseti'l-Endelûsiyye fi't-Tefsîr: Sifâtüh ve Hasâisuh", es-Sicillü'l-Ilmiyyü li Nedveti'lEndelüs, haz.: Abdullah b. Ali ez-Zeydân, vd., Riyad 1996, s. 224.

36 Bu kabule örnek olarak bk. Takıyüddîn Ahmed İbn Teymiye (728/1328), Mukaddime fî Usûli'tTefsîr, Dâru'ş-Şâmir li't-Türâs, Beyrut 1988, s. 117. İmâdüddîn Ebu'l-Fidâ İsmail İbn Ömer İbn Kesîr (774/1372), Tefsîru'l-Kur'âni'l-Azîm, tahk.: Muhammed İbrahim Bennâ ve Arkadaşları, Kahraman Yay., İstanbul 1984, c. 1, ss. 12.

37 Bk. Suat Yıldırım, Peygamberimizin Kur'anı Tefsiri, Kayıhan Yay., İstanbul 1998, s. 31 vd. 
sahabe bizzat Kur'ân'ın nüzûl sürecini yaşamaları, Hz. Peygamber'in tedrîsinden geçmeleri, kırâatlere ve nüzûl sebeplerine vâkıf olmaları gibi özellikleriyle Kur' an tefsîrinde kaynaktır. ${ }^{38}$ Bunlara ilaveten tâbiûn, sahabe ile sonraki nesiller arasında köprü olması, kırâat ve sebeb-i nüzûllere ait bilgileri ile tefsîr tarihinde haklı olarak dördüncü kaynak kabul edilir. ${ }^{39}$

Konuyu 'Endülüs'te tefsîrin kaynakları nelerdi?' sorusu bağlamında ele aldığımız zaman bölgede yapılan tefsîrin kaynaklarının klasik tefsîr anlayışından farklı olmadığı görülmektedir. Endülüslü müfessirler de tefsîrlerinde Kur'ân'in Kur'ân, sünnet, sahabe ve tâbiûn sözü ile tefsîri şeklinde özetlenebilecek rivâyet tefsîrini esas almışlar ve câiz re'y tefsîrini de bunun üzerine binâ etmişlerdir. ${ }^{40}$

Meşînî, Endülüs'te sonraki dönemlerde yazılmış tefsîr kitaplarının hangilerinden yararlanıldığına dair 'doğu ve diğer kaynaklar' başlı̆̆ı altında Tefsîr' den Kırâat'e, Fıkıh'tan Kelâm'a bir dizi eserin adını zikreder. Bunlar arasında Tefsîr'e dâir Taberî'nin (310/922) el-Câmiu'l-Beyân'1, Nehhâs'in (338/949) I'râbu'lKur'ân ile Meâni'l-Kur'ân'1, Nakkâş'ın (351/962) Şifâu's-Sudûr'u, Mâverdî'nin (450/1058) en-Nüket ve'l-Uyûn'u, Tûsî'nin (460/1067) et-Tibyân'ı, Kuşeyrî'nin (465/1072) Letâifü'l-İşârât' '1, İlkiyâ el-Harrâsî'nin (504/1110) Ahkâmu'l-Kur'ân'1, Zemahşerî'nin (538/1143) el-Keş̧̧âf', Râzî'nin (606/1209) Mefâtihu'l-Gayb'1, İbnü'n-Nakîb'in (698/1298) et-Tahrîr ve't-Tehcîr'i, Mehdevî'nin (430/1038) etTahsîl'i, Mekkî b. Ebî Tâlib'in (437/1045) el-Hidâye'si gibi eserler, Kırâat İlmine dâir ise Ebû Ali el-Fârisî'nin (377/987) Kitâbü'l-Hucce'si, İbn Cinnî'nin (392/1001) Kitâbü'l-Muhteseb'i ve Ebû Amr ed-Dânî'nin (444/1052) Kitâbü't-Teysîr'i ile Câmiu'l-Beyân fi'l-Kırââti's-Seb'a'sı yer almaktadır. ${ }^{41}$

M. Akif Koç da Endülüslü müfessirlerin en önemli kaynağı olarak Taberî'yi görür. ${ }^{42}$ Taberî'nin bütün bir tefsîr tarihine olduğu gibi Endülüs'e de etkisi tartışılmaz. Ancak Yahyâ b. Sellâm'ın (200/815) bölge tefsîrine etkisi unutulmamalıdır. Çünkü o, İmam Mâlik'in (179/795) Muvatta'ı'nın râvîlerinden biri

38 İsmail Cerrahoğlu, Tefsir Tarihi, Fecr Yay., Ankara 1996, c. 1, ss. 67.

39 Muhsin Demirci, Tefsir Tarihi, İfav Yay., İstanbul 2003, s. 94.

40 Meşînî, age, ss. 114-115, 147-148; Rûmî, age, s. 190.

41 Meşînî, age, ss. 115-124. Bölge tefsîrinin Meşînî'ye benzer şekilde doğulu ve batılı kaynaklar şeklinde tasnîfi için ayrıca bk. Vâfî, age, ss. 13-14.

42 Mehmet Akif Koç, “Endülüs Tefsirciliği Üzerine Bir Giriş Denemesi”, İslâmiyât, sayı: 3, Ankara 2004, s. 47. 
kabul edilmektedir. ${ }^{43}$

\section{Endülüs Tefsîr Kültürünün Özellikleri}

Endülüslü müfessirler, Kur'ân lafızlarının manâ ve delâletlerini idrâk etmek, maksad ve murâdını anlamak için Arap dilini tefsîrin en önemli referansı kabul etmişlerdir. Bu sebeple dilbilgisini müfessirin sahip olması gereken ilimlerden kabul etmişlerdir. ${ }^{44}$ Bölgedeki eğitim anlayışı, Kur'ân öğretiminden sonra Sarf, Nahiv, Yazı gibi dil eğitimine öncelik ve ağırlık vermiş̧tir. ${ }^{45}$ Rivâyet tefsîrinin yanı sıra dilbilim açıklamalarına dayanan yorumlama biçiminin Endülüs tefsîrinin ayırıcı özelliği olduğu da söylenilmiştir. ${ }^{46}$ Bölge müfessirleri arasında dilciliğiyle öne çıkanlar, İbn Atıyye ve Ebû Hayyân olmuşlardır. Çünkü ikisi de bölgenin bütün tarihi içinde nahiv âlimi ve imamı sayılmışlardır. Ancak hemen belirtilmelidir ki Ebu Hayyân bu konuda İbn Atıyye'nin önüne geçmiştir. ${ }^{47} \mathrm{O}$ kadar ki onun tefsîri filolojik tefsîr alanındaki en önemli kaynaklardan olup ${ }^{48}$ Hüseyin ez-Zehebî'nin (1399/1978) ifadesiyle tefsîr kitapları içerisinde nahiv kitaplarına en yakın tefsîrdir. ${ }^{49}$

Bölge müfessirleri selefin yaklaşımı olan klasik tefsîr usûlüne uygun olarak; Kur'ân'1, rivâyet ve dirâyet metodunu bir arada kullanarak anla(t)maya çalışmışlardır. Bu yöntemi tefsîrlerine yazdıkları mukaddimelerinde benimsediklerini ifade etmişler ve tefsîrlerinde buna uymuşlardır. ${ }^{50}$

Örneğin bize göre ${ }^{51}$ Endülüs'te rivâyet'ten dirâyete geçişin dönüm noktasında bulunan İbn Atıyye, kıssaların ancak âyetin anlaşılmasına yarayacak kadarına yer verdiğini, selefin anlayışına göre ve Arapça'nın kurallarını göz önü-

43 Vâfî, age, s. 15.

44 Meşînî, age, ss. 469, 604.

45 Muhammed Abdülhamîd Îsâ, age, s. 235

46 Vincent J. Cornell, “'Ilm Al-Qur'an in Al-Andalus: The Tafsir Muharrar in the Works of Three Authors", JUSUR, s. 2, 1986, s. 64.

47 Meşînî, age, ss. 470-47, 604.

48 M. Vecih Uzunoğlu, el-Bahru'l-Muhît'in Filolojik Açıdan Incelenmesi, (Yayınlanmamış Doktora Tezi), Dokuz Eylül Ü. Sosyal Bilimler Enstitüsü, İzmir, 2006, ss. 140, 320.

49 Muhammed Hüseyin ez-Zehebî (1399/1978), et-Tefsîr ve'l-Müfessirûn, Kahire, 1381/1961, c. 1, s. 318.

50 Meşînî, age, ss. 591-592.

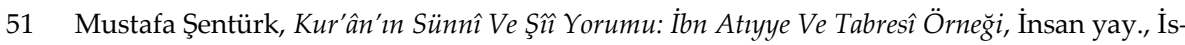
tanbul, 2010, ss. 193-196. 
ne alarak âlimlerin Kur'ân'ın anlamlarına dair kendilerine nispet edilen görüşlerini tespit ettiğini söylemiştir. İşârî, bâtınî vb. sapkın yorumlardan uzak durduğunu belirterek tefsîrini âyetlerin lafızlarını birçok tefsîrde olduğu gibi bırakıp ötesine geçmediğini, bilakis lafızları esas alıp âyetleri hüküm, nahiv, lügat, manâ ve kırâatleri yönünden açıklayarak yazdığını ifade etmiştir. Müsta'mel ve şâzz bütün kırâatlere yer verdiğini, sağlam açıklamalara dayanıp lafızların içerdiği bütün muhtemel manaları dikkate aldığını belirtmiştir. ${ }^{52}$

Ebû Hayyân da âyeti sebeb-i nüzûl, siyak-sibak irtibâtı, nâsih-mensûh, i'râb, kırâat ve hüküm açlarından ele aldığını; âyetin tefsîrinde selef ve halef ulemâsının görüşlerine yer verdiğini söylemiştir. ${ }^{53}$

Kenûnî’ye göre Endülüs'teki tefsîr anlayışı üç maddede özetlenebilir:

1. Kırâatleri isnâd, nakil ve hıfz açılarından incelemek ve onlardan yardım almak sûretiyle Kur'ân metnini belgelemeye önem vermek,

2. Kur'ân'ı i'râb, nesh ve i'câz açılarından anlamaya çalışmak,

3. Kur'ân'ın anlamı üzerinde düşünüp doğru hükümleri çıkarmaktır. ${ }^{54}$

Belirttiğimiz gibi Endülüslü müfessirler için esas olan rivâyet metodudur. $\mathrm{Bu}$, dirâyet metodundan uzak durdukları anlamına gelmez. Tefsîrde rivâyeti esas almak, yapılan tefsîrin câiz olması ve sadece re'ye dayanmamak şartıyla dirâyet metodunu da kullanmışlardır. ${ }^{55}$ Yorumlarında Kur'ân'a, sahîh hadîslere dayanıp zayıf ve mevzû olanlardan uzak durmaya çalışmışlardır. Genellikle tefsîrlerinde yer verdikleri hadîslerin senedlerini ve kaynaklarını göstermemişlerdir. Sahabe ve tâbiûn görüşlerini dikkate alıp delillerle destekleyebildiklerini esas almışlardır. ${ }^{56}$ Örneğin Mekkî b. Ebî Tâlib, tefsîrinde Hz. Peygamber'den (sas) gelen sahîh rivâyetlere, sahabe ve tâbiûnun meşhur te' vîllerine, dilbilimcilerin, fakîhlerin ve kurrâ' nın görüşlerine, hâsılı rivâyet ve dirâyet ehlinin değerlendirmelerine yer verdiğini belirtmektedir. ${ }^{57}$

Kırâatlere anlam ve hüküm açısından, ayrıca dilci ve müfessirlerin kırâatle

52 Ebû Muhammed Abdülhak el-Endelüsî İbn Atıyye (541/1147); el-Muharraru'l-Vecîz fì Tefsîri'lKitâbi'l-Azîz, tahk.: Abdüsselâm Abdüşşâfî, Dâru'l-Kütübi'l-İlmiyye, Beyrut 2001, c. 1, ss. 3435 .

53 Muhammed b. Yûsuf Ebû Hayyân (745/1344); el-Bahru'l-Muhît, tahk.: Adil Ahmed Abdülmevcûd, vd., Dâru'l-Kütübi'l-illmiyye, Beyrut 1993, c. 1, s. 103.

54 Kenûnî, age, c.1, s. 294.

55 Meşînî, age, s. 593.

56 Meşînî, age, s. 892.

57 Mekkî b. Ebî Tâlib, age, c. 1, s. 72 . 
ilgili yaklaşımlarını ilmî kritikten geçirmek ve şâz kırâatler karşısında mütevâtir olanlarını korumak için yer vermişlerdir. ${ }^{58}$ Bölgenin öncü müfessirlerinden Mekkî b. Ebî Tâlib'e göre bir kırâatin sahîh olabilmesi için Hz. Peygamber'den sahîh bir senetle rivâyet edilmesi, Arapça'nın dilbilim kurallarına ve Hz. Osman Mushafı'na uygun olması gerekmektedir. ${ }^{59}$ Belirtildiğine göre daha önce kırâatların "sahih" ve "şâz" olarak nitelendirilmeleri belli imamlara isnad edilirken Mekki b. Ebî Tâlib’ den itibaren bu yöntem yerini söz konusu kurallara bırakmıştır. ${ }^{00}$

Örneğin İbnü'l-Arabî (543/1148), birden fazla kırâatin bulunmasını kolaylık ve Allah'ın kulları üzerindeki rahmeti olarak değerlendirmiş, bu doğrultuda şâz olanlar hâriç bütün kırâatlerin Kur'ân olduğunu ve hepsiyle hüküm verilebileceğini ve namaz k1lınabileceğini ifade etmiştir. ${ }^{61}$

Endülüs müfessirlerinin çoğu bölgelerinde kadılık yapmışlardır. Bu bakımdan tefsîrlerinde ahkâm âyetlerine ve fıkhî hükümlere önem vermişler ve yorumlarını, bölgede en yaygın mezheb olan Mâlikî fıkhı çerçevesinde yapmışlardır. Bilindiği gibi fıkhî tefsîr İbnü'l-Arabî ve Kurtubî' nin tefsîrlerinin isimlerinde bile kendisini gösterir. Onlar haklı olarak bu yönleriyle, İbn Atıyye ve Ebû Hayyân'a göre daha meşhûrdurlar. ${ }^{62}$

Kurtubî'nin (671/1272) en önemli kaynakları arasında yer alan İbnü'lArabî, eserinde 108 sûrede, ahkâm âyetleri olarak değerlendirdiği 850 küsür âyetin tefsîrini yapmıştır. ${ }^{63}$

Kurtubî, tefsîrinde sahih rivâyetlere ve sahibine nispet ederek yer vereceğini belirttikten sonra âyetlerin manalarını açığa çıkaracak hükümlerini, sebebi

58 Meşînî, age, s. 317-319. Rûmî, age, ss. 212-213.

59 Mekki b. Ebî Talib, el-i̇bâne an Meâni'l-Kırâat, Dâru Nahdâh, tahk.: Abdülfettâh İsmâîl Şelebî, Misir, ts., s. 51.

60 Arif Güneş, Kur'an-ı Kerim'in Okunmasında Harf-Kıraat-Yazı Kavramı İlişkileri, Yayınlanmamış Doktora Tezi, Ankara Ü. Sosyal Bilimler Enstitüsü, Ankara, 1992, s. 24.

61 Ebû Bekr İbnü'l-Arabî (543/1148), Ahkâmü'l-Kur'ân, Dâru İhyâi't-Türâsi'l-Arabî, Beyrut, 1. Bsk., c. 1, s. 92, c. 2, ss. 521-522, c. 3, s. 510, c. 4, s. 108.

62 Bu konuda geniş bilgi için bk. Meşînî, age, ss. 473-527.

63 Bayram, İbnü'l-Arabî'nin ahkâm âyetleri yorumlarıyla ilgili olarak 108 sûre, 852 âyet sayısını verirken Hocaoğlu ise sûre sayısı belirtmeden âyet sayısı olarak 872 sayısını verir. Bk. Abdullah Bayram, Kurtubîve Fıkhî Tefsiri, Yayınlanmamış Doktora Tezi, Uludağ Ü. Sosyal Bilimler Enstitüsü, Bursa 2008, s. 100; Mustafa Hocaoğlu, Ahkâm Tefsirlerinin Usûl Açısından Mukayesesi: Cessâs, Herrâsî ve İbn Arabî Örnekleri, Yayınlanmamış Doktora Tezi, Dokuz Eylül Ü. Sosyal Bilimler Enstitüsü, İzmir 2010, s. 8. 
nüzûlü, bilinmeyen (garîb) kelimeleri açıklayacağını belirtir. ${ }^{64}$

Tasavvuf, Endülüs'te çok rağbet görmeyen, hatta eleştiriye tâbi tutulan bir alan olmuştur. ${ }^{65}$ Bu sebeple işârî tefsîr, Endülüslü müfessirlerce pek kabul görmez. Çünkü onlara göre işârî yorumlar hezeyânlarla doludur ve Allah'a iftirâ ile âyetlerden sapmadır. ${ }^{66}$

İbn Atıyye mukaddimesinde işârî, bâtınî vb. yorumları sapkın yorumlar olarak niteler, bunlardan uzak durduğunu belirtir. Birçok tefsîrde olduğu gibi kendi tefsîrinde âyetlerin lafızlarını bırakıp ötesine geçmediğini, bilakis lafızları esas alıp âyetleri hüküm, nahiv, lügat, manâ ve kırâatler yönünden açıklayarak yazdığını ifade eder. ${ }^{67}$

Ebû Hayyân tasavvuf erbâbının görüşlerine de yer verdiğini ancak lafızlara yükledikleri olumsuz manalara itibar etmediğini, ayrıca Allah ve Hz. Ali adına bir takım saçmalıkları uyduran sapkın bâtınî görüşleri terk ettiğini ifade eder. 68

Endülüs coğrafyasında Mâlikî mezhebinin etkisiyle Kelâm ve Felsefe'ye çok ilgi gösterilmediği belirtilmiştir. ${ }^{99}$ Bunun bir sonucu olarak Mu'tezile ve fikirleri bölgede tutunamamıştır. Dolayısıyla bu coğrafyadaki tefsîrlerde mu'tezilî metod ve fikirlere ancak eleştirmek ve cevap vermek için yer verilmiştir. Çünkü bölgede tartışmasız Ehl-i Sünnet'in hâkimiyeti vardır.70

İbn Atıyye, Mutezile'yi haramın rızk olmadığını söylediği, sıfatları inkâr ettiği, kulların kendi fiillerinin yaratıcısı olduğu ve îmân-küfür, hidâyetdalâletin kulların inisiyatifinde olduğunu iddia ettiği, kabir azabını reddettiği,

64 Ebû Abdullah Muhammed b. Ahmed el-Kurtubî (671/1272), el-Câmi' li Ahkâmi'l-Kur'ân, tahk.: Hişâm Semîr el-Buhârî, Dâru İlmi'l-Kütüb, Riyad 2003, c. 1, s. 3.

65 Maribel Fierro, “Endülüs'te Tasavvufa Muhalefet”, Uludă̆ Üniversitesi Illâhiyât Fakültesi Dergisi, çev.: Semih Ceyhan, c. 18, s. 2, Bursa 2009, ss. 327-359; Necmettin Bardakç1, “İbnü’l-Arabî Öncesi Endülüs'te Tasavvuf", Tasavvuf, sayı: 23, 2009, s. 326.

66 Meşînî kitabında İbn Arabî'den İbn Atıyye, Kurtubî ve Ebû Hayyân'a kadar Endülüslü müfessirlerin işârî tefsîre bakışının genelde olumsuz olduğunu belirterek bunu örneklendirir. Bk. Meşînî, age, ss. 639-650

67 İbn Atiyye, age, c. 1, s. 34 .

68 Ebû Hayyân, age, c. 1, s. 104.

69 Özdemir, agm, c. 10, s. 221; Mehmet Özdemir, "IX. Yüzyıl Endülüs'ünde Zındıklık Suçlamaları", Ankara Üniversitesi i̇lâhiyât Fakültesi Dergisi, Ankara, c. 38, ss. 219-220. Felsefenin Endülüs coğrafyasında ancak Muvahhidler döneminde (1147-1229) yayılmaya başladığı ile ilgili olarak bk. Muhammed Abdülhamîd Îsâ, age, s. 199.

70 Meşînî, age, s. 670 
şefâati kabul etmediği, husün ve kubhu aklın belirlediğini iddia ettiği, çift ecel kabul ettiği, ru'yetullahı kabul etmediği ve Kur'ân'ı mahlûk kabul ettiği için eleştirir. ${ }^{71}$

İsrâiliyât konusuna gelindiğinde Endülüs'teki müfessirler isrâiliyâta karşı temkinli yaklaşmışlar, doğuracağı sonuçları dikkate alarak tefsîrlerinde pek yer vermemişler ve ondan kaçınmışlardır. İsrâîlî bilgilerin, bölgenin ortak bir kararı gibi buradaki tefsîrlerin hepsinde çok az bulunduğunu söyleyebiliriz. Konuya genellikle bu bilgileri reddetmek için değinmişlerdir. ${ }^{72}$ Ancak Endülüs tefsîrinin öncülerinden Mekkî b. Ebî Tâlib'in (437/1045) isrâîliyyâtı herhangi bir eleştiriye tâbi tutmadan eserinde zikrettiği belirtilmiş, sebep olarak da Endülüs dişında, Kayravan'da yetişmesi gösterilmiştir. ${ }^{73}$ Nitekim tefsîrinde örneğin Nûh'un (as) gemisiyle ilgili bilgiler verirken bu türden haberleri nakletmektedir. ${ }^{74}$

İbn Atıyye bir terim olarak isrâiliyyât kavramına yer verip bunun için bir tanım ve ilke belirlemese de isrâîlî kitaplardan alınan bilgilere atıfta bulunur. ${ }^{75}$ Atıflardan ${ }^{76}$ anladığımız kadarıyla İbn Atıyye bu bilgilere, sadece yanlışlığına dikkat çekmek için yer verir.

Ebû Hayyân da tefsîrinin mukaddimesinde doğru olmayan sebeb-i nüzûl bilgisine, fezâil hadîslerine, uygun olmayan kıssa ve isrâîlî haberlere yer veren müfessirleri eleştirir ve bu tür bilgilerin tefsîr ilmi için bir gereklilik olmadığını belirtir. ${ }^{77}$

Özetle Endülüs'te oluşan tefsîr anlayışının, klasik tefsîr geleneği gibi olduğu ve Kur'ân'ın Kur'ân, sünnet, sahabe ve tâbiûn görüşleri ile yapılan rivâyet tefsîrini temel almak ve dirâyet tefsîrini bunun üzerine inşâ etmek şeklinde olduğu söylenebilir. Endülüs'teki tefsîr kültürü kırâatlere ve dilbilimsel açıklamalara önem vermek, işârî/bâtınî, felsefî ve isrâîlî yaklaşımlardan uzak durmak şeklinde kendisini göstermektedir.

71 İbn Atyye, age, c. 1, ss. 53, 85, 106, 266, 287, 323, 340, 404. c. 2, ss. 29, 330, 360, 380, 383, 395, 396. c. 3 , s. 76 , c. 4 , ss. 364,534 , c. 5 , s. 36 .

72 Meşînî, age, ss. 529-586. Benzer bir değerlendirme için bk. Mehmet Akif Koç, agm, ss. 52-23.

73 Ahmed Hasan Ferhat, Mekkî b. Ebî Tâlib Ve Tefsîru'l-Kur'ân, Dâru Imâr, Amman 1997, s. 274. Endülüs tefsîrinin özellikleriyle ilgili krş. Rûmî, age, 220-223; Yunus Ekin, agm, ss. 262-265.

74 Mekkî b. Ebî Tâlib, age, c. 5, ss. 3384-3393.

75 İbn Atryye, age, c. 2, s. 445 , c. 3, s. 221, c. 4, s. 499 , c. 5, s. 168

76 İbn Atryye, age, c. 2, s. 445, c. 3, ss. 220-221, c. 2, ss. 498-499.

77 Ebû Hayyân, age, c. 1, s. 104. 


\section{Endülüs Tefsîr'de Bir Ekol Oluşturabilmiş midir?}

Meşînî, bizim de çokça yararlandığımız kitabına Medresetü't-Tefsîr fi'l-Endülüs (Endülüs'te Tefsîr Okulu/Ekolü) adını vermiş, ancak kitabında ayrı bir kategori olarak "Endülüs Tefsîr Ekolünden" söz edilip edilemeyeceğini tartışmaya açmadan Endülüs'te üretilen tefsîr literatürünün özgün olduğunu savunmuştur. Aslında tefsîrin Doğuda ve Batıda kuralları, şartları, kaynakları ve metodlarının aynı olduğunu belirttikten sonra her nedense Endülüs tefsîrinin iki açıdan özgün/müstakil olduğunu iddia etmiştir:

Birincisi, eğilim bakımından özgün olduğunu, buna göre bölge tefsîrinin sapkın eğilimlerden uzak, ilhâd ve zındıklık içerisindeki çeşitli itikâdî fırkaların görüşlerinden berî olup Sünnî/selefî çizgiyi temsîl ettiğini, halbuki doğuda durumun böyle olmadığını ve Doğu İslâm Dünyası'na felsefenin girdiğini, düşünce ve itikad alanında çeşitli fırkaların yayıldığını, bunun sonucu olarak da doğuda itizâlî, işârî ve bâtınî tefsîr hareketlerinin yayıldığını söyler.

İkincisi, yöntem ve te'lîf açısından özgün olduğunu, buna göre de bölge müfessirlerinin çoğunlukla sadece nakille yetinmemeleri, çeşitli fikirlere yer verip onları kritik etmeleri ya da yeni fikirler ileri sürmeleri, üslûp ve yöntemde taklîdle yetinmeyip tercihlerini ortaya koymaları ve tefsîrlerini gereksiz kıssa ve tarihsel bilgiler ile isrâiliyattan mümkün olduğunca uzak tutmaları olduğunu belirtir.78

Öte yandan aslında yöntem ve te'lîf alanında tam bir özgünlüğün olamayacağını, çünkü Tefsîr ilminin kural ve şartlarının âlimler arasında tartışma konusu olmayacak kadar belli olduğunu ve bu açıdan Endülüslü müfessirlerin doğulu âlimlerden etkilendiğini ve mesela Taberî́den çok yararlandıklarını söyler. ${ }^{79}$

Bu çerçevede Meşînî, iki başlık halinde Endülüslü müfessirler ile Doğulu müfessirleri karşılaştırır:

a) Yöntem açısından: Doğulu müfessirler, tefsîrlerinde takip edecekleri yöntemi genellikle açıklamazlarken, İbnü'l-Arabî'den Ebû Hayyân'a kadar Endülüslü müfessirler tefsîrlerinde yöntemlerini ve üzerinde duracakları konuları gerekçeleriyle beraber açıklarlar. Ona göre bu yöntem, Endülüslü müfessirler dışında örneği çok az bulunan güzel bir yoldur.

78 Meşînî, age, ss. 716-718.

79 Meşînî, age, s. 718. 
b) İçerik açısından: Meşînî bu konunun üzerinde ciddî araştırmalar yapılması gerektiğini belirttikten sonra her iki grubu re'y tefsîri, kırâatler, dil ve isrâiliyât alt başlıklarıyla karşılaştırır..$^{80}$ Örnek olarak o, re'y tefsîri açısından yaptığı karşılaştırma sonunda her iki grubun da Kur'ân'ın Kur'ân, sünnet ve sahabe ve tâbiûn sözü ile tefsîrine önem verdiklerini, dahası bu tefsîri, tefsîrin esası kabul ettiklerini; ancak meselâ Taberî'nin naklettiği hadîs ya da görüşlerin senedlerini verdiğini; Zemahşerî, Râzî, Nisâbûrî, İbn Atıyye ve Ebû Hayyân'ın senedlere yer vermeden, sadece metni verdiklerini söyler. ${ }^{81}$ Bize göre Meşînî'nin Endülüs tefsîrinin özgünlüğü ispatlamak için ortaya koyduğu veriler ve yaptığ 1 değerlendirmeler yeterli değildir. Çünkü kendisinin de belirttiği gibi tefsîrin Doğuda ve Batıda kural, kaynak ve metodları farklı değildir. Öte yandan çeşitli sapkın görüşlerden uzak olmak ve nakille yetinmeyip yeni görüşler ortaya koymak ve tefsîrlerinde takip edecekleri metodları açıklamak sadece Endülüs'e has değildir. Yine kendi ifadesiyle her iki kültür coğrafyası da tefsîrde rivâyet tefsîrini esas kabul edip dirâyet tefsîrini onun üzerine inşâ etmiştir. Coğrafya ve zamanın şartlarından kaynaklanan farklar ise, bize göre en azından bu iki bölge için özgünlük oluşturacak düzeyde değildir.

Özetleyecek olursak bizim bu çalışmada cevap aradığımız sorulardan biri de "Endülüs Tefsîr Geleneği özgün müdür?" sorusudur. Yaptığımız araştırmaya dayanarak biz, Doğu İslâm Dünyasının, bir başka ifadeyle merkezî İslâm anlayışının dışında; sözgelimi Şîa Tefsîri gibi ayrı “özgün bir Endülüs tefsîr geleneğinden" söz edilemeyeceği kanaâtine ulaşmış bulunuyoruz. Çünkü yukarıda değinegeldiğimiz gibi Endülüslü müfessirler, merkezle bağlarını koparıp da klasik kırâat ve tefsîr kaynaklarından ayrı bir kaynak silsilesi ya da metodu takip etmiş değillerdir. Öte yandan bölge Sünnî/Mâlikî çizgidedir ve bilindiği gibi bu çizgi de merkezî İslâm düşüncesinden farklı değildir. Ayrı bir kategori olarak Endülüs'te oluşan bir tefsîr geleneğinden söz edebilmek için burada oluşan tefsîr anlayışının kaynakları, metodolojileri, bölgede yapılan tefsîrin dinî, sosyal ve siyâsî âmillerinin incelenmesi ve bunların klasik tefsîr anlayışından farklılıklarının ortaya konulması gerekir. Elbette tefsîre zamanın ve coğrafyanın sosyo-politik ve kültürel rengi yansır. Ancak biz bu rengin ayrı bir gelenek oluşturmak için yeterli olmadığı ve bu sebeple Endülüs'te klasik tefsîr geleneğinden ayrı bir tefsîr geleneği oluşturmadığı düşüncesindeyiz.

80 Ayrıntılı bilgi için bk. Meşînî, age, ss. 719-826.

81 Meşînî, age, s. 746. 
Bizden farklı olarak Endülüslü müfessirlerin Kur'ânı anlama ve yorumlama tekniklerinin özgün ve ayırıcı vasıflar içerdiğini söyleyen araştırmacılar da bulunmaktadır. Ancak söz konusu çalışmada bu niteliklerin neler olduğundan açıklıkla söz edilmediği, üstelik bölge müfessirlerinin kaynaklarının Kitap, Sünnet, lügat, nahiv, kırâat, sahabe kavli, şiir ve ictihâd olarak zikredildiği ve sahabe kavline bakışlarının da Ebû Hanîfe'ye paralel olduğu belirtilmektedir ${ }^{82}$. Oysa bize göre klasik tefsîr anlayışı da bundan çok farklı değildir. O halde özgünlük ve fark nerededir?

Bir başka araştırmacı ise bizim bu düşüncemize paralel olarak eldeki malzemenin Endülüs tefsîrinin 'farklılıklarından' değil ancak 'önceliklerinden' söz etmeye izin verdiğini belirtir. ${ }^{83} \mathrm{Bu}$ açıdan bakıldığında bize göre, Endülüslü müfessirlerin tefsîr metodolojileri geleneksel tefsîr anlayışından çok farklı değildir ve genel olarak Kur'ân'ın Kur'ân, sünnet, gelenek (sahabe, tâbiûn, mezheb imamları) ve ictihad ile tefsîri şeklinde özetlenebilir.

\section{Değerlendirme ve Sonuç}

Endülüs'te tefsîr çalışmalarının diğer islâmî ilimlerle birlikte bölgenin İslamlaşması sürecinde bölgeye girdiği ve ayrı bir disiplin olarak tefsîr faaliyetlerinin h. III. asrın ilk yarısında başladığı söylenebilir. İbn Atıyye ile birlikte h. VI. asırda bölge tefsîrinin olgunlaşmasını tamamladığı ve o andan itibaren bölgenin karakteristiğini yansıtan tefsîrlerin yazılmaya başlandığı görülmektedir.

Bölgede dilbilim ve ona bağlı olarak kırâat, tefsîr ve fıkhın en çok değer verilen ilimlerden olduğu, bunun bir sonucu olarak da bölge müfessirlerinin tefsîrlerinde dilbilimsel açıklamalara, kırâat tahlillerine ve fıkhî izahlara yer verdikleri görülmektedir.

Endülüs kültür havzasındaki tefsîr anlayışı, klasik tefsîr anlayışından farklı olmayıp, Kur'ân'ın Kur'ân, sünnet, sahabe ve tâbiûn görüşleri ile yapılan rivâyet tefsîrini esas almak; dirâyet tefsîrini de bunun üzerine inşâ etmek şeklinde özetlenebilir. Bölgedeki tefsîr kültürü özellikle kırâatlere ve dilsel açıklamalara önem vermek; işârî/bâtınî, felsefî ve isrâîlî yaklaşımlardan uzak durmak şeklinde kendisini göstermektedir.

Bize göre Endülüs'te yapılan tefsîr çalışmaları, kaynakları ve metodları açısından özgün değildir. O nedenle biz yukarıda belirttiğimiz nitelikleri taşı-

82 Ekin, agm, ss. 263-264.

83 Koç, agm, s. 58. 
yan bu tefsîr kültürünün, Endülüs'te özgün bir tefsîr ekolü oluşturacak özellikler olduğu değerlendirmelerine değil; bu özelliklerin bölge tefsîrinin öncelikleri olduğu değerlendirmelerine katılıyoruz.

Belki Endülüs'ün katkısı, tefsîri gereksiz ayrıntılardan ve aşırılıklardan arındırarak daha sistematik, sorgulamacı, eleştirel ve daha çok mesaj odaklı olarak mevcut tefsîr birikimini günümüze taşımada etkin bir aracılık işlevi görmek şeklinde özetlenebilir.

\section{Kaynakça}

Arînî, Yûsuf b. Ali b. İbrâhîm; el-Hayâtü'l-İlmiyye fi'l-Endülüs fì Asri'l-Muvahhidîn, Riyad 1995.

Atçeken, İsmail Hakkı; "Endülüs'ün fetih Süreciyle İlgili Farklı Görüşlere Eleştirel Bir Yaklaşım”, Selçuk Üniversitesi Ilâhiyât Fakültesi Dergisi, sayı: 19, Konya 2005.

Atik, M. Kemal; “Endülüs ve Kur'an İlimlerindeki Yeri”, Erciyes Üniversitesi Illâhiyât Fakültesi Dergisi., sayı: 2, Kayseri 1985.

Bardakçı, Necmettin; “İbnü'l-Arabî Öncesi Endülüs'te Tasavvuf”, Tasavvuf, sayı: 23, 2009.

Bayram, Abdullah; Kurtubî ve Fıkhî Tefsiri, Yayınlanmamış Doktora Tezi, Uludağ Ünv. SBE, Bursa 2008.

Beşerî, Sa'd Abdullah Sâlih; el-Hayâtü'l-İlmiyye fì Asri Mülûki't-Tavâif fi'l-Endelüs, Riyad, 1993.

-------, el-Hayâtü'l-İlmiyye fî Asri'l-Hılâfe fi'l-Endelüs, Mekke 1997.

Cerrahoğlu, İsmail; Tefsir Tarihi, Fecr Yay., Ankara, 1996.

Cornell, Vincent J.; “'Ilm Al-Qur'an in Al-Andalus: The Tafsir Muharrar in The Works of Three Authors", JUSUR, s. 2, 1986.

Dadan, Ali; “Endülüs Adının Kökeni Üzerine”, İSTEM, sayı: 14, Konya 2009.

Demirci, Muhsin; Tefsir Tarihi, İ́av Yay., İstanbul 2003.

Ebû Hayyân, Muhammed b. Yûsuf (745/1344); el-Bahru'l-Muhît, tahk.: Adil Ahmed Abdülmevcûd, vd., Dâru'l-Kütübi'l-İlmiyye, Beyrut, 1993.

Ekin, Yunus; “Endülüs Tefsir Geleneği”, Sakarya Ünv. Ilâhiyât Fak. Der., sayı: 3, Sakarya 2001.

Ferhat, Ahmed Hasan; Mekkî b. Ebî Tâlib Ve Tefsîru'l-Kur'ân, Dâru Imâr, Amman 1997.

Fierro, Maribel; “Endülüs'te Tasavvufa Muhalefet”, çev.: Semih Ceyhan, Uludă̆ Ünv. İlâhiyât Fak. Der., c. 18, s. 2, Bursa 2009.

Güneş, Arif; Kur'an-ı Kerim'in Okunmasında Harf-Kıraat-Yazı Kavramı İlişkileri, Yayınlanmamış Doktora Tezi, AÜ, SBE, Ankara 1992.

Hitti, Philip K.; Siyâsî Ve Kütürel İslam Tarihi, çev.: Salih Tuğ, Boğaziçi Yay., İstanbul 1980.

Hocaoğlu, Mustafa; Ahkâm Tefsirlerinin Usûl Açısından Mukayesesi: Cessâs, Herrâsî ve İbn Arabî Örnekleri, Yayınlanmamış Doktora Tezi DEÜ SBE, İzmir.

İbnü'l-Arabî, Ebû Bekr (543/1148); Ahkâmü'l-Kur'ân, Dâru İhyâi't-Türâsi'l-Arabî, Beyrut, 1. bsk.

İbn Atıyye, Ebû Muhammed Abdülhak el-Endelüsî (541/1147); el-Muharraru'l-Vecîz fì Tefsîri'lKitâbi'l-Azîz, tahk.: Abdüsselâm Abdüşşâ̂, Dâru'l-Kütübi'l-İlmiyye, Beyrut 2001.

İbn Haldun, Abdurrahmân (808/1405); Mukaddime, Dâru İhyâi't-Türâsi'l-Arabî, Lübnan, trs.

İbn Kesîr, İmâdüddîn Ebu'l-Fidâ İsmail İbn Ömer (774/1372); Tefsîru'l-Kur'âni'l-Azîm, tahk.: Muhammed İbrahim Bennâ ve Arkadaşları, Kahraman Yay., İstanbul 1984. 
İbn Teymiye, Takıyüddîn Ahmed (728/1328); Mukaddime fí Usûli't-Tefsîr, Dâru'ş-Şâmir li't-Türâs, Beyrut, 1988.

İbnü'l-Cezerî, Muhammed (833/1429); Gâyetü'n-Nihâye fî Tabakâti'l-Kurrâ', Misır 1932.

İmamüddin, S. Muhammed; Endülüs Siyasi Tarihi, çev.: Yusuf Yazar, Rehber Yay., Ankara, 1990. Îsâ, Muhammed Abdülhamîd; Târîhu't-Ta'lîm fi'l-Endelüs, Dâru'l-Fikri'l-Arabî, yy., 1982.

Kazanc1, F. Asiye Şenat; “Endülüslü Kıraat Âlimi Dânî ve Teysîr'i”, Türk-İslâm Medeniyeti Akademik Araştırmalar Dergisi, s. 10, 2010.

Kandemir, M. Yaşar; “Bakî b. Mahled”, DIA, (Türkiye Diyanet Vakfı İslam Ansiklopedisi),İstanbul 1991.

Kenûnî, Abdüsselâm Ahmed; el-Medresetü'l-Kur'âniyye fi'l-Magrib, Mektebetü'l-Maârif, Rabat 1981.

Koç, Mehmet Akif; “Endülüs Tefsirciliği Üzerine Bir Giriş Denemesi”, İslâmiyât, sayı: 3, Ankara 2004.

Kurtubî, Ebû Abdullah Muhammed b. Ahmed (671/1272); el-Câmi' li Ahkâmi'l-Kur'ân, tahk.: Hişâm Semîr el-Buhârî, Dâru İlmi'l-Kütüb, Riyad 2003.

Makkarî, Ahmed b. Muhammed (1041/1632); Nefhu't-Tîb, tahk.: İhsan Abbâs, Dâru Sâdır, Beyrut 1968.

Mekkî b. Ebî Tâlib, Ebû Muhammed (437/1045), el-Hidâye ilâ Bülûgi'n-Nihâye, tahk.: eş-Şâhid elBuşeyhî, vd., Mecmûatü Buhûsi'l-Kitâbi ve's-Sünne, Câmiatü'ş-Şârika, 2008.

-------, el-i̇bâne an Meâni'l-Kırâât, Dâru Nahdâh, tahk.: Abdülfettâh İsmâîl Şelebî, Mısır, ts..

Meşînî, Mustafa İbrâhîm Medresetü't-Tefsîr fi'l-Endelüs, Müessesetü'r-Risâle, Beyrut 1986.

Özdemir, Mehmet; “Endülüs”, DIA, (Türkiye Diyanet Vakfı İslam Ansiklopedisi), İstanbul 1995. , "IX. Yüzyıl Endülüs'ünde Zındıklık Suçlamaları”, Ankara Üniversitesi İlâhiyât Fakültesi Dergisi, c. 38, Ankara, trs.

Rûmî, Fehd İbn Abdurrahmân İbn Süleymân; “Menhecü'l-Medreseti'l-Endelûsiyye fi't-Tefsîr: Sifâtüh ve Hasâisuh", es-Sicillü'l-Ilmiyyü li Nedveti'l-Endelüs, haz.: Abdullah b. Ali ez-Zeydân, vd., Riyad 1996.

Şentürk, Mustafa; Kur'ân'ın Sünnî Ve Şî̀ Yorumu: İbn Atryye Ve Tabresî Örneği, İnsan Yay., İstanbul 2010.

Uzunoğlu, M. Vecih; el-Bahru'l-Muhît'in Filolojik Açıdan İncelenmesi, (Yayınlanmamış Doktora Tezi), Dokuz Eylülk Ü. Sosyal bilimler Enstitüsü, İzmir 2006.

Vâfî, İbrâhîm Ahmed; "et-Tefsîr Ve Ulûmu'l-Kur'âni bi'l-Garbi'l-İslâmiyyi mine'1-Karni's-Sânî ile'lKarni's-Sâmini'l-Hicrî", es-Sicillü'l-Ilmiyyü li Nedveti'l-Endelüs, haz.: Abdullah b. Ali ezZeydân, vd., Riyad 1996.

Yıldırım, Suat; Peygamberimizin Kur'anı Tefsiri, Kayıhan Yay., İstanbul 1998.

Zehebî, Muhammed Hüseyin (1399/1978); et-Tefsîr ve'l-Müfessirûn, Kahire 1381/1961. 